\begin{tabular}{|l|l|l||}
\hline \multicolumn{2}{|c|}{ PublisherInfo } \\
\hline \hline PublisherName & $:$ & BioMed Central \\
\hline \hline PublisherLocation & $:$ & London \\
\hline \hline PublisherImprintName & $:$ & BioMed Central \\
\hline \hline
\end{tabular}

\title{
IFN maintains anergic cell survival
}

\begin{tabular}{|l|l|l||}
\hline \multicolumn{2}{|c||}{ ArticleInfo } \\
\hline \hline ArticleID & $:$ & 139 \\
\hline \hline ArticleDOI & $:$ & $10.1186 /$ ar-2000-66857 \\
\hline \hline ArticleCitationID & $:$ & 66857 \\
\hline \hline ArticleSequenceNumber & $:$ & 96 \\
\hline \hline ArticleCategory & $:$ & Paper Report \\
\hline \hline ArticleFirstPage & $:$ & 1 \\
\hline \hline ArticleLastPage & $:$ & 3 \\
\hline \hline & & RegistrationDate : 2000-10-13 \\
ArticleHistory & $:$ & OnlineDate $\quad$ 2000-10-13 \\
\hline \hline ArticleCopyright & $:$ & Current Science Ltd2000 \\
\hline \hline ArticleGrants & $:$ & \\
\hline \hline ArticleContext & $:$ & 130753311 \\
\hline \hline
\end{tabular}


Aff1 St James University Hospital, Leeds, UK

\section{Keywords}

Anergy, apoptosis, IFN

\section{Context}

Following suboptimal stimulation through the $\mathrm{T}$ cell receptor, cells either undergo apoptosis or become anergic. Anergic cells have been shown to survive for extended periods in vivo, suggesting that anergic cells must be able to escape apoptosis. Previous studies have demonstrated that interferan (IFN)$\hat{I}^{2} \hat{I} \pm$ can prevent $\mathrm{T}$ cell apoptosis induced by cytokine deprivation. This study aimed to show that IFN$\hat{I}^{2} \hat{I} \pm$ is the major survival factor for anergic $T$ cells.

\section{Significant findings}

$\mathrm{T}$ cell clones were incubated with specific peptide in the absence of antigen-presenting cells. This T:T presentation led to cell death mediated by CD95. When cells were co-cultured with fibroblasts or fibroblast-conditioned media, cell death was significantly reduced. Addition of anti-IFN-Ît antibodies to the media significantly reduced the anti-apoptotic activity. IFN-Î \pm prevented apoptosis by inducing STAT-1 activity and blocking protein kinase C-Î' translocation to the nucleus. Importantly this study demonstrated that the cells rescued from cell death were all anergic. The authors conclude that IFN-Î2 $\hat{I} \pm$ rescues $\mathrm{T}$ cells from CD95-mediated apoptosis; this mechanism of rescue may account for the persistence of anergic cells in vivo.

\section{Comments}

There is currently great interest in discovering what influences the cell fate decisions made by $\mathrm{T}$ cells following stimulation through their $\mathrm{T}$ cell receptor. This study suggests that the micro-environment may determine whether cells become anergic or apoptotic. It focuses on IFN as the main factor for T cell survival; however, it is important to note that other soluble factors may be implicated by the present data. The model used, namely T:T presentation, could occur in vivoand the authors postulate that it may 
be a mechanism of producing anergic immunoregulatory cells. Previously, the authors demonstrated that IFN-ÎI $\hat{I} \pm$ maintains $T$ cell survival in the rheumatoid arthritis synovium. They suggest that local secretion of IFN may also promote survival of anergic cells. Such anergic cells may contribute to the maintenance of tolerance by active regulation.

\section{Methods}

Co-culture, anergy induction, STAT analysis, PKC staining

\section{References}

1. Lombardi G, Dunne PJ, Scheel-Toellner D, Scheel-Toellner D, Pilling D, Taams LS, Life P, Lord JM, Salmon M, Akbar AN: Type 1 IFN maintains the survival of anergic CD4 ${ }^{+} \mathrm{T}$ Cells. J Immunol. 2000, 165: 3782-3789.

This PDF file was created after publication. 